\title{
Review on Advanced Glycation End Products and the Progress of Chronic Disorders
}

\author{
Elaheh Foroumandi ${ }^{1}$ and Abdolhassan Kazemi ${ }^{2 *}$ \\ ${ }^{1}$ Department of Nutrition, Faculty of Nutrition and food sciences, Tabriz University of Medical Sciences, Iran \\ ${ }^{2}$ Professor of Molecular Biology \& Genetic Engineering, Tabriz University of Medical Sciences, Iran
}

Submission: February 12, 2018; Published: March 14, 2018

*Corresponding author: Abdolhassan Kazemi, Professor of Molecular Biology \& Genetic Engineering, Faculty of Medicine, Tabriz University of Medical Sciences, Tabriz, Iran, Email: Kazemi1338@Gmail.com

\author{
Abstract \\ The study of AGEs represents one of the most promising areas of research today. This review covers the information and generation of AGEs \\ in the field of disorders, which will be useful for biomedical professionals.
}

Keywords : Advanced glycation end products, chronic disorders, Amadori product

\section{Introduction}

Advanced glycation end products are a complex and heterogeneous group of compounds that is produce by nonenzymatic and spontaneous reactions of the carbonyl group of carbohydrates with proteins, nucleic acids or lipids through a series of reactions. In fact this process have two step:

i. The condensation of a sugar aldehyde with a free amino group of proteins (usually hydroxylysine or arginine residues) forming a non-stable Schiff base

ii. Formation of Amadori products from Schiff base.

This glycation process, is also known as the Millard action which was described in the early 1912's, by Louis-Camille Maillard. The Schiff base and especially Amadori products may undergo oxidation, dehydration, and polymerization to rise other AGEs. The AGEs that formed under oxidative conditions called advanced glycoxidation end products [1].

\section{Exogenous AGEs}

Animal and human based studies have shown that along with endogenously production of AGEs in the body, exogenous AGEs can found naturally in many foods and tobacco. They are in the foods that cooked at high temperatures, especially animalderived products that are rich in protein and fat. Indeed, some of the cooking methods including barbecuing, grilling, roasting, and frying may contribute to higher dietary AGEs [2]. Unfortunately, the differentiation of dietary AGEs type, amount and destructive mechanism with endogenously AGEs is not well known.

\section{Most commonly AGEs}

Pentosidine is a fluorescent glycoxidation product that is isolated by Sell and Monnier, as the common known AGEs. It can form by cross linking the glucose, fructose, or ascorbate to an arginine and a lysine residue [3].

Carboxymethyl-lysine (CML) also known as N (epsilon)(carboxymethyl) lysine is a well-characterized and nonfluorescent AGEs that was first described by Ahmed in 1985. The CML formed by oxidation of fructosyl-lysine as an Amadori product or by reaction of glyoxal with the amino group of lysine [4]. It is the most prevalent marker for AGEs concentrations analysis in the foods.

\section{Dicarbonyl compounds}

Dicarbonyl compounds derive from oxidative degradation or autoxidation of Amadori products, which are leading to protein crosslinks. Methylglyoxal (MGO), glypxal (GO) and 3-deoxyglucosone (3-DG) are three well-known dicarbonyl compounds [5].

\section{Receptors of AGEs}

AGEs do not only act by altering the physicochemical properties of glycated proteins. Interestingly, many cells in the body such as endothelial cells and smooth muscle have receptors for binding AGEs (RAGEs). These receptors are not specific for AGEs, as other molecules such as S-100/calgranulins, amphoterine, $\beta$-amyloid peptides and $\beta$-sheet fibrils can bind them [6]. Excess accumulation of AGEs in the body may adversely affect these cells.

\section{AGEs in disorders}

AGEs affect nearly every type of cell and molecule in the body, which have pathogenic role in some conditions that causes intracellular damage and apoptosis. Recent studies has 
been work done to elaborate on the treatment and prevention of related complications to some disorders including aging, coronary artery disease, kidney failure, Alzheimer's disease, osteoarthritis, and diabetes and demonstrated that most of the complications especially in diabetes patients are due to the accumulation of AGEs [7]. Chronic disorders are significantly associated with oxidative stress in humans and animals, as decreased expression of antioxidative enzymes along with NADPH oxidase activation are contribute to high production of ROS in the tissues. Activation of nuclear factor (NF)- $\kappa B$, and JNK pathways is accompanied by obesity, high-fat diet, and cellular stresses (ROS), which can increase inflammatory responses in body tissues. Some ligands including TNFR, IL-1R, and RAGE that are receptors for TNF- $\alpha$, IL-1, and AGEs can also activate the JNK pathway during metabolic dysregulation [8]. The processes that are occurred in diseases are the principal causative factors for formation of AGEs.

\section{Conclusion}

The study of AGEs represents one of the most promising areas of research today. Long-term formation of AGEs affects all long-lived proteins, which they can only be removed from the body when the protein is removed. Therefore, many health professionals are calling for AGE levels to become a marker of overall health. Although, most of the AGEs have not yet been isolated or characterized, Pentosidine, CML, and some Dicarbonyl compounds such as MGO are used to identifying AGEs concentrations in the body. Methylglyoxal has been suggested to be a better marker for investigating the association between AGEs with adverse health outcomes.

\section{References}

1. Goldin A, Beckman JA, Schmidt AM, Creager MA (2006) Advanced glycation end products: sparking the development of diabetic vascular injury. Circulation 114(6): 597-605.

2. Sharma C, Kaur A, Thind S, Singh B, Raina S (2015) Advanced glycation end-products (AGEs): an emerging concern for processed food industries. Journal of food science and technology 52(12): 7561-7576.

3. Grandhee SK, Monnier VM (1991) Mechanism of formation of the Maillard protein cross-link pentosidine. Glucose, fructose, and ascorbate as pentosidine precursors. Journal of Biological Chemistry 266(18): 11649-1153.

4. Delgado-Andrade C (2016) Carboxymethyl-lysine: thirty years of investigation in the field of AGE formation. Food \& function 7(1): 4657.

5. Scheijen JL, Schalkwijk CG (2014) Quantification of glyoxal, methylglyoxal and 3-deoxyglucosone in blood and plasma by ultra performance liquid chromatography tandem mass spectrometry: evaluation of blood specimen. Clinical chemistry and laboratory medicine 52(1): 85-91.

6. Fleming TH, Humpert PM, Nawroth PP, Bierhaus A (2011) Reactive metabolites and AGE/RAGE-mediated cellular dysfunction affect the aging process-a mini-review. Gerontology 57(5): 435-443.

7. Singh R, Barden A, Mori T, Beilin L (2011) Advanced glycation endproducts: a review. Diabetologia 44(2): 129-146.

8. Shoelson SE, Lee J, Goldfine $\mathrm{AB}$ (2006) Inflammation and insulin resistance. The Journal of clinical investigation 116(7): 1793-801.

Your next submission with Juniper Publishers
will reach you the below assets
- Quality Editorial service
- Swift Peer Review
- Reprints availability
- E-prints Service
- Manuscript Podcast for convenient understanding
- Global attainment for your research
- Manuscript accessibility in different formats
( Pdf, E-pub, Full Text, Audio)
- Unceasing customer service
Track the below URL for one-step submission
https://juniperpublishers.com/online-submission.php

